Wilfrid Laurier University

Scholars Commons @ Laurier

\title{
Preferences, Perceptions, and Veto Players: Explaining Devolution Negotiation Outcomes in the Canadian Territorial North
}

Christopher Alcantara

Wilfrid Laurier University, calcantara@wlu.ca

Follow this and additional works at: https://scholars.wlu.ca/poli_faculty

Part of the Comparative Politics Commons

\section{Recommended Citation}

Alcantara, Christopher, "Preferences, Perceptions, and Veto Players: Explaining Devolution Negotiation Outcomes in the Canadian Territorial North" (2012). Political Science Faculty Publications. 30.

https://scholars.wlu.ca/poli_faculty/30

This Article is brought to you for free and open access by the Political Science at Scholars Commons @ Laurier. It has been accepted for inclusion in Political Science Faculty Publications by an authorized administrator of Scholars Commons@ Laurier. For more information, please contact scholarscommons@wlu.ca. 


\section{Preferences, perceptions, and veto players: explaining devolution negotiation outcomes in the Canadian territorial north}

\section{Christopher Alcantara}

Department of Political Science, Wilfrid Laurier University, Waterloo, ON N2L 3C5, Canada

(calcantara@wlu.ca)

Received October 2011; first published online 29 February 2012

ABSTRACT. Since the early part of the 20th century, the federal government has engaged in a long and slow process of devolution in the Canadian Arctic. Although the range of powers devolved to the territorial governments has been substantial over the years, the federal government still maintains control over the single most important jurisdiction in the region, territorial lands and resources, which it controls in two of the three territories, the Northwest Territories and Nunavut. This fact is significant for territorial governments because gaining jurisdiction over their lands and resources is seen as necessary for dramatically improving the lives of residents and governments in the Canadian north. Relying on archival materials, secondary sources, and 33 elite interviews, this paper uses a rational choice framework to explain why the Yukon territorial government was able to complete a final devolution agreement relating to lands and resources in 2001 and why the governments of the Northwest Territories and Nunavut have not. It finds that the nature and distance of federal-territorial preferences, combined with government perceptions of aboriginal consent and federal perceptions of territorial capacity and maturity, explain the divergent outcomes experienced by the three territorial governments in the Canadian arctic.

The following acronyms are employed: AIP: Agreement-in-Principle; DTA: Devolution Transfer Agreement; GEB: gross expenditure base; GN: Government of Nunavut; GNWT: Government of Northwest Territories; NCLA: Nunavut Land Claims Agreement; NTI: Nunavut Tunngavik Incorporated; NWT; Northwest Territories; ON: Ontario; TFF: Territorial Formula Financing; UFA: Umbrella Final Agreement; YDTA: Yukon Devolution Transfer Agreement; YTG: Yukon Territorial Government; YK: Yukon;

\section{Introduction}

Residents in Canada's three northern territories have long faced significant challenges relating to living and governing in the arctic. Recognising this fact, the federal government has, since the early part of the 20th century, engaged in a long and slow process of devolution, which is the transfer of province-like powers such as health care, education, social services, transportation, public works, and local government to the territorial governments (Dacks 1990; Dacks and Coates 1988; White 2002). It has also negotiated with the Inuit to create the territory of Nunavut in 1999, and negotiated with other aboriginal groups to create aboriginal governments in the Yukon Territory and the Northwest Territories (NWT). With these devolved powers, politicians and policymakers hope that the territorial governments of Yukon, NWT, and Nunavut can better manage and address the challenges particular to their regions (Okalik 2006; O'Brien 2006; Rayner 2001).

Although the range of powers devolved to the territorial governments has been substantial, the federal government still maintains partial control over the single most important jurisdiction in the region, territorial lands and resources, which it controls in two of the three territories, NWT and Nunavut. This fact is significant for territorial governments because gaining jurisdiction over their lands and resources is seen as necessary for dramatically improving the lives of territorial residents and governments in the Canadian north (Abele and Prince 2008; Irlbacher-Fox and Mills 2007; McArthur 2007; O'Brien 2006; Rayner 2001). Indeed, territorial lands have long been known to contain vast deposits of highly sought after non-renewable resources, which could provide substantial long term revenues for the territorial governments (Abele 2009: 41-42; Government of Northwest Territories 1998; Grady 2001: 4).

In 2001, the Yukon territorial government negotiated a devolution agreement with the federal government that gave it control over its lands and resources in 2003 (Government of Canada and Government of the Yukon 2001; Natcher and Davis 2007). In contrast, negotiations to complete similar devolution agreements with the governments of the NWT and Nunavut have yet to come to fruition. Although the government of Nunavut (GN) has signed a protocol agreement and the government of the Northwest Territories (GNWT) has signed an agreementin-principle (AIP) with the federal government (for the NWT, see Memorandum 2001; Government of Canada and others 2004; for Nunavut see Government of Canada and others 2008; Mayer 2007), a number of informed observers and recent events indicate that neither territory is likely to complete a final devolution agreement in the near future.

In light of the importance of devolution to the economic and social prosperity of Canada's territorial communities and governments, this paper seeks to address the following question: why was the Yukon territorial government able to achieve a devolution agreement relating to land and resources in 2001, and why have the NWT and Nunavut governments not been able to complete such an agreement? To answer these questions, 
this paper relies on 33 semi-structured open interviews with federal, territorial, and aboriginal officials in Ottawa, ON, Whitehorse, YK, and Yellowknife, NWT, archival materials gathered from the National and NWT Archives, and relevant government documents, reports, and secondary materials. The evidence suggests that variation in devolution negotiation outcomes can best be explained by examining the preferences and relative bargaining power of the negotiating governments, the federal government's perceptions of territorial maturity and capacity, and the actions of the aboriginal veto players in each territory.

The paper is organised as follows. It begins with a historical sketch of devolution and the political/ constitutional development of the three territories. Next, it specifies the theoretical framework that guides the analysis before illustrating how this framework explains the divergent outcomes. The paper concludes with a discussion of the main findings.

\section{Background considerations}

The purpose of this section is to paint a brief historical sketch of the political and constitutional development of the territorial north. It focuses mainly on the NWT and Yukon, emphasising that their territorial governments were created originally as administrative regions to be controlled directly by federal civil servants and bureaucrats. Over time, however, the federal government has devolved a comprehensive set of province-like powers and jurisdictions and allowed them to develop democratic, representative, and responsible government. However, much as it did when it created the provinces of Alberta and Saskatchewan, the federal government has delayed handing over lands and resources, finally transferring those jurisdictions only to the Yukon territorial government in 2003, and not to the others.

\section{The Northwest Territories}

The NWT, acquired from Britain in 1870, has deep historical significance for Canada. Six of Canada's ten provinces were entirely carved or partially derived from the NWT's frontiers over the course of the country's history. As well, both the Yukon Territory in 1898 and Nunvaut in 1999 were created out of the lands of the NWT. The NWT, therefore, has long been crucial to the nation-building project of Canada.

The federal government's passing of the Northwest Territory Act of 1875 marked the establishment of the domestic legal basis for Dominion authority over the region. This legislation confirmed the interim provisions put in place by the federal government in 1870, which established its direct control over, and delivery of basic services to, the region. In 1905, the NWT Act was amended to create the position of commissioner as chief executive officer of the region, and established an advisory Territorial Council made up of four appointed civil servants from Ottawa. In 1919, the deputy minister of the Department of the Interior was appointed permanent Commissioner of the Territory, solidifying the bureau- cratic and Ottawa-centric nature of governance in the territory (Dickerson 1992: 29-30).

During the 1960s, the federal government became interested in fostering greater autonomy in the north and created the Carrothers Commission to examine the issue. The commission recommended a number of things, including replacing the Territorial Council with a legislative assembly and creating a new territorial government and bureaucracy in Yellowknife. Even before the Carrothers Commission issued its final report, however, the federal government in early 1964 appointed B.G. Sivertz as head of a small territorial government office in Ottawa to begin the transition. In 1965, the NWT Council passed a public service ordinance to provide a legal basis for the creation of a territorial bureaucracy (Zaslow 1988: 361). Federal legislation in 1966 established a consolidated revenue fund for the territorial government, giving it a measure of financial independence. By the summer of 1967, the new territorial government had appointed department heads and hired staff members to replace federal officials from the Northern Administration Branch (Zaslow 1988: 365-6) and by October 1967, social services, transportation and public works were devolved to the new territorial government. Health remained a divided responsibility while in the field of education, the GNWT assumed control over all schools run by the federal government. By 1969, and in a single stroke of administrative devolution', the GNWT had assumed nearly all of the responsibilities that its provincial counterparts enjoyed, except for natural resources (including oil, gas, inland fisheries and forest management), and full responsibility over health care delivery (Clancy 1990: 28).

With devolution mostly complete, territorial officials turned their attention to establishing responsible government and a fully elected NWT Council. By 1970, only four appointed members remained on the 14-member council. By 1975, the first fully elected NWT Council took power, which was renamed the Legislative Assembly in 1976, and for the first time chose its own speaker and two members of the Executive Committee. The Assembly also succeeded in eventually gaining control over the number of constituencies in the territory and immediately created 22 electoral constituencies. Later, it would name seven members to the Executive Council, reducing the number of unelected officials to two (Legislative Assembly of the Northwest Territories 2010).

In 1980, the members of the assembly elected their first government leader, George Braden. He finished the process of creating full responsible government in the territory by removing the commissioner and deputy commissioner from the Executive Council in 1985 and replacing them with elected members from the assembly. In 1994, the assembly voted to change the title of government leader to premier and bestow that title retroactively on all those who served as government leader since 1980 (Legislative Assembly of the Northwest Territories 2010). 
Despite these important developments, the political/ constitutional development of the NWT is incomplete because NWT lands and resources remain in the hands of the federal government. During the mid to late 1980s, the federal government indicated a willingness to transfer lands and resources to the territories and began negotiations on oil and gas (Dacks 1990: 241-243). Despite extensive negotiations during the 1990s and 2000s, including the signing of a highly controversial agreement in principle in early 2011, the GNWT and the federal government have yet to generate a final agreement. The recent 2011 NWT territorial election and interview data suggest that a final agreement is unlikely to be completed in the foreseeable future.

\section{Yukon Territory}

One of the main reasons for creating the Yukon Territory out of the western portion of the NWT was to deal with the gold rush during the $1890 \mathrm{~s}$. With the arrival of almost 50,000 people to the Klondike, including many Americans, Ottawa felt the need to maintain sovereignty and order in the area. Thus, the federal government passed the Yukon Act in 1898, creating the Yukon Territory out of the western portion of the NWT (Bone 2002: 6).

Early government in Yukon was similar to that in the NWT. The Yukon Act empowered the Governor in Council to administer the territory and allowed it 'appoint for the Yukon Territory a chief executive officer to be styled and known as the Commissioner of the Yukon Territory' (Canada 1898). Much as in the NWT, the commissioner had significant control over the territory and was accountable only to Ottawa rather than to the residents of Yukon (Morrison 1968: 20). To help the commissioner with his duties, the Governor in Council appointed a Yukon Council of six people (Canada 1898). Gradually, the number of appointed members of the council decreased until 1908 when all members became elected members.

During the period between 1918 and 1950, the political development of Yukon was retrenched. In 1919, for instance, the federal government reduced the size of the council from ten to three elected members (Coates and Morrison 2005: 188). However, a number of developments in the 1940s and onwards reinvigorated the political development of the territory, leading to the reestablishment of the commissioner in 1948 and the expansion of the Yukon Council from three to five members (Cameron and White 1995: 18). In 1961, the Yukon Act was amended yet again through the establishment of an Advisory Committee on Finance, which was made up of three elected Yukon Council members (Smyth 1991: 28, 289). The commissioner was now obligated to consult this advisory committee during budget preparations, thus creating a measure of limited responsible government (Cameron and White 1995: 20).

Also during this period, the civil service was reorganised and enlarged to deal with a variety of issues and to clarify territorial and federal responsibilities in the region
(Michael 1987: 74). The federal government then began to devolve some responsibilities to the Yukon government, such as justice in 1971 and the Alaska Highway and fisheries in 1972, to name a few. In 1970, the federal government asked Commissioner James Smith to create an Executive Committee made up of himself, two elected members of council, and two assistant commissioners (Smyth 1991: 37). This was a significant step toward responsible government, and for the first time in Yukon, 'elected officials were given portfolio responsibilities in the administration of government and seats in the executive body' (Cameron and White 1995: 21).

With the creation and development of the Executive Committee as well as the introduction of party politics in 1978, a form of representative government had finally developed. In June 1979, full responsible government arrived when the Yukon territorial elected member and leader, Chris Pearson, wrote a letter to federal minister of Indian Affairs Jake Epp asking him to remove the commissioner from the Executive Committee, abolish the deputy commissioner, and rename the Executive Committee, the Executive Council. After receiving the letter, Epp wrote to Commissioner Ione Christensen, instructing her to ask the Territorial Government Leader, now to be called Premier, to form an executive cabinet made up of elected members of the Yukon Territorial Council. The commissioner was instructed that he was now bound to follow the advice of the council and the government leader on all matters (Cameron and Gomme 1991: 161).

Leading up to the devolution transfer agreement of 2001, a number of important responsibilities were transferred to the Yukon Territory. During this decade, the territorial government gained full control over health services in the territory (Health Canada 2005). It also received control over onshore oil and gas through the Yukon Oil and Gas Accord in 1998 (Irlbacher-Fox and Mills 2007: 5). At the same time during this period, discussions commenced to transfer responsibility over lands and natural resources to the territorial government. The process began in 1996 when the Minister of Indian Affairs and Northern Development, Ronald Irwin, released a consultation paper entitled 'Devolution of the Northern Affairs Program to the Yukon Government' (Hurley 2009). This paper facilitated the signing of an accord that outlined the process for devolution. Several years later, the negotiating parties completed devolution negotiations by signing the Devolution Transfer Agreement (DTA) on 29 October 2001.

By signing the DTA, the Canadian government agreed to replace the Yukon Act with new legislation that provided the Yukon legislature with the authority to make laws concerning public land and water (Hurley 2009). In addition, the Canadian government repealed the Yukon Placer Mining Act, the Yukon Quartz Mining Act, and the Yukon Waters Act so that the Yukon government could develop legislation to replace these federal laws. Devolution was finally complete. 


\section{Nunavut}

The territory of Nunavut was the result of a comprehensive land claims agreement signed in 1993 by the Inuit in the eastern Arctic of Canada, the federal government of Canada, and the GNWT. In addition to granting the Inuit signatories a variety of land rights and jurisdictions, it also contained provisions for a political accord that would establish a new territory in the eastern Arctic (Henderson 2007: 1). The new territory, which came into being in 1999, adopted a public government structure, meaning that all residents could vote and run for office. The government is led by a premier, who is assisted by a cabinet made up of elected representatives from the legislative assembly, which must work with a 19member legislative assembly to pass legislation. In terms of devolution, the GN benefited from the timing of its creation in 1999 when all major powers and jurisdictions were already transferred to the GNWT except for lands and natural resources. Thus, the GN enjoys many of the same powers and jurisdictions that the Yukon territorial government and the GNWT have except for lands and resources (White 2009). Although the GN has expressed an interest in beginning negotiations with the federal government over this final issue, negotiations have yet to occur beyond the creation of a devolution protocol that outlines how devolution negotiations might proceed in the future (Mayer 2007).

\section{Explaining devolution: a theoretical framework}

So what explains the success of the Yukon territorial government in negotiating a final devolution transfer agreement in 2001 and what explains the failure of the governments of the NWT and Nunavut to do the same? Devolution negotiations relating to territorial lands and resources are somewhat similar to comprehensive land claims negotiations. In both cases, for instance, negotiating actors seek to redistribute a certain set of collective goods, which in this case is lands and resources (Alcantara 2007, 2008). There are a number of important differences, however. Modern treaties involve the transfer of ownership rights whereas devolution negotiations relating to land and resources involve the transfer of administrative control (Armstrong 2010; Dewar 2010). Whereas comprehensive land claims negotiations are trilateral, devolution negotiations are typically bilateral, between the territorial government and the federal government of Canada (Dacks 1990; McArthur 2007). The one exception may be Nunavut, since informal discussions in the past have included Nunavut Tunngavik Inc., responsible for looking after land claims post treaty, at the table (Rawson 2010; Mayer 2007). Nonetheless, formal territorial devolution negotiations are generally bilateral, with the federal and territorial governments coming to the table with a set of goals that they hope to achieve in a final agreement.

The likelihood of being able to achieve a final devolution agreement is strongly dependent on the distance between the preferences of the negotiating governments (see Alcantara 2008; Simeon 2006: 14-15; Tsebelis 2002). Preferences are the goals that the negotiating actors have during negotiations relating to territorial lands and resources. Yet the content and distance of preferences alone do not by themselves explain negotiation outcomes. Power relations are important for structuring the relationship between negotiating actors in these situations (Alcantara 2008; Simeon 2006; Tsebelis 2002). Much like aboriginal treaty negotiations, devolution negotiations involve government participants with significant power differentials, which in this case favour the federal government over the territorial government. Territorial governments, for instance, do not enjoy the same constitutional status as provinces and, at least in the case of the NWT and Yukon, they exist somewhat at the pleasure of the federal government (Cameron and White 1995; Smyth 2010). More importantly, all of the negotiation stakes, such as land and natural/human resources, are by default in the hands of the federal government and the federal government has no obligation to transfer control of these jurisdictions immediately to the territorial governments. Indeed, territorial governments do not have access to something akin to 'aboriginal rights and title' or 'aboriginal traditional territories' to bolster their devolution claims. As a result, the federal government is in essence a veto player (Tsebelis 2002) during devolution negotiations, and the likelihood of the negotiating parties completing a final agreement will depend on the ability of territorial governments to satisfy somehow the preferences and expectations of the federal government. Failure to do so will result in the federal government exercising its veto, meaning it will continue to administer territorial lands and resources until the territorial government can meet the preferences and expectations of the federal government.

The exact set of factors that generate a final devolution agreement are very much context-specific. In addition to the differences in power resources among the negotiating actors, the negotiating environment also plays a role in specifying the exact nature of federal government expectations. In comprehensive land claims negotiations, the aboriginal actors have to adopt compatible goals with those of the federal, provincial, and/or territorial governments, to minimise the use of confrontational tactics, to foster internal group cohesion, and to generate positive government perceptions of the aboriginal group (Alcantara 2007). In devolution negotiations, the federal government is interested not only in a final agreement that is compatible with its preferences, but it will also only complete a final agreement with those territorial governments that it views as politically mature (Bannon 2011; Richardson 2011; Wright 1995), and with those territorial governments that it perceives to have achieved a 'critical mass of support' among aboriginal groups in the region. Indeed, a number of anonymous and nonanonymous interviewees (Bannon 2011; Dewar 2010; Leas 2010; McDonald 2010; Richardson 2011), as well 
as archival documents (Intergovernmental and Aboriginal Affairs 1994: 2, 1995: 2), have stressed that this critical mass of aboriginal support, a threshold which has been left intentionally vague, is necessary before the federal government will sign a final devolution agreement. Over time, the territorial governments have also gradually internalised this requirement as part of their own negotiation strategies and processes. This is especially true in the NWT and Nunavut where the proportion of aboriginal people within their borders is large. Thus, aboriginal actors in the three territories act as additional veto players in territorial devolution negotiations, even though they are not directly involved in the bilateral negotiations.

In sum, devolution negotiations are similar to treaty negotiations in that negotiating parties seek to maximise their preferences. However, power differentials between the territorial and federal governments mean that territorial governments must meet the expectations and preferences of the federal government. These expectations and preferences are context-specific, reflecting on the one hand the significant differences in power resources among the negotiating governments, and the political context of the Canadian territorial north on the other. In terms of the latter point, devolution has been a long and incremental process in the Canadian arctic, reflecting the federal government's desire to transfer powers to the territorial governments only when they are deemed to be mature enough to handle the responsibilities (Bannon 2011; Braden 2011; Handley 2011; McKinnon 2010; Smyth 2010; Wright 1995). Politics in the north is also very much dominated by the large and influential presence of aboriginal groups (Abele and others 2009; Dacks 1990; McArthur 2007), and thus devolution negotiations very much require a consideration of aboriginal consent even if aboriginal groups are not directly involved in the formal bilateral negotiations.

This paper uses elements of rational choice and game theory to explain variation in devolution negotiation outcomes in the Canadian territorial north. Some readers, however, might argue that these theoretical tools are inappropriate because territorial devolution is highly complex and diverse, whereas rational choice and game theory rely on the simplification of situations to their basic elements. The basic argument here is that complex situations require complex theories.

The legitimacy of this criticism, however, depends heavily on the relationship between complexity and theory. According to King, Keohane, and Verba (1994: 9-10), 'social science constitutes an attempt to make sense of social situations that we perceive as more or less complex. We need to recognise, however, that what we perceive as complexity is not entirely inherent in phenomena: the world is not naturally divided into simple and complex sets of events. On the contrary, the perceived complexity of a situation depends in part on how well we can simplify reality, and our capacity to simplify depends on whether we can specify outcomes and explanatory variables in a coherent way ... . Thus "complexity" is partly conditional on the state of our theory.'

In other words, in the absence of objective measures for determining which political situations and phenomena are complex and which are not, such a determination will rely heavily on the theoretical framework employed. Indeed, even the task of choosing objective measures is inherently difficult, since the choice of measures will depend heavily on the theory used by the researcher. As such, it would be a mistake to reject rational choice and game theoretical approaches to the study of territorial governance solely on the basis of a mismatch between a theory's assumptions about complexity and the reader's preferred theoretical approach to the study of a political phenomenon.

In the next section of the paper, I present some empirical evidence to illustrate how the extent to which territorial goals are compatible with those of the federal government, the level at which the federal government perceives the territorial government's political maturity, and government perceptions regarding the achievement of aboriginal consent, have generated different outcomes for the three territorial governments in the Canadian north.

\section{Explaining devolution: some empirical evidence}

\section{Specifying the preferences}

Given the importance of preferences in determining outcomes, the following section specifies the preferences of the federal, territorial, and aboriginal actors involved in devolution negotiations in the Canadian arctic. Beginning with the federal government, federal officials have long been interested in the territorial north for a variety of reasons. Broadly speaking, federal policy has long been driven by the nation-building imperative, in which the political development of the Canadian territories was seen as the last frontier in the construction of a fully mature and independent Canada (Cameron and Campbell 2009: 199; Coates and others 2008: 201; Richardson 2011; Robertson and others 2010). Tied to this objective has been a strong and consistent desire to defend the sovereign interests of the Canadian government in the region against competing claims by other nations (Coates and others 2008: 59, 116). In terms of the devolution of lands and resources specifically, however, federal preferences centre strongly around the economic potential of the Canadian north (Chretien 1969: 2). Mark Dickerson (1992) and others (Coates and others 2008) have illustrated how the political and constitutional development of the Canadian north have long been driven by the federal government's desire to exploit the natural resources of the region, which requires the creation of infrastructure, human resources and capacity, and local/territorial government. As such, according to three anonymous federal government interviewees, two anonymous GNWT interviewees, and one former GNWT official, federal policymakers have long viewed the natural resources of 
the north as 'Canadian resources' that belong to, and should benefit, the entire country (Richardson 2011). This approach is consistent with federal views about equalisation, in which all provinces should benefit instead of only certain provinces or regions benefiting disproportionately (Expert Panel on Equalization and TFF 2005: 8-9; Intergovernmental Core Group 1993: 32). Overall, therefore, federal preferences relating to the devolution of lands and resources revolve around the desire to maximise resource revenues while maintaining a consistent approach to dividing those revenues among the federal and sub-national units in the federation. The content of these preferences as they relate to the devolution of lands and resources are confirmed by interview data from two anonymous GNWT officials, two anonymous former senior federal officials, and two non-anonymous officials (Bannon 2011; Richardson 2011).

A number of interviewees also suggested that the federal government is driven to reduce its costs related to administering territorial lands, resources, and programmes, simply because these costs are significant (Government of Northwest Territories 1995; Government of Northwest Territories 1993: 2; Robertson and others 2010). Several anonymous federal and former senior federal officials, for instance, mentioned that it was not coincidence that the first things that were devolved to the territorial governments were programmes that cost money, such as education, social services, and health care, and that the main revenue generating jurisdictions, such as land and resources, were left to the end (see also Handley 2011). The recent budgets of the territorial governments are revealing for illustrating the costliness of governance in the Canadian north. In 2006-2007, for instance, Yukon government expenditures were $\$ 813,864,000$ while revenues were $\$ 844,783,000$, with the latter amount including $\$ 609,715,000$ in federal transfers. Similarly, in NWT, expenditures during that fiscal year were $\$ 1,205,111,000$ while revenues were $\$ 1,203,778,000$, with the latter amount including $\$ 879,318,000$ in federal transfers. In Nunavut, expenditures during 2006-2007 were $\$ 1,110,906,000$ while revenues were $\$ 1,218,558,000$, which includes $\$ 1,132,547,000$ in federal transfers. As a result, the federal government has long been interested in devolving the responsibility of these direct costs to the territorial governments as means of helping to control federal expenditures writ large.

In short, federal preferences in devolution negotiations relating to territorial land and resources are very much driven by the desire to maintain revenue streams, decrease direct costs, and ensure that territorial shares of natural resource revenues are consistent with federal principles of equalisation (Intergovernmental Core Group 1993: 32). The natural resources of the north have long been seen as important to the economy of the country and the federal government wants to ensure that those revenues continue to flow into the national economy post-devolution (Expert Panel on Equalization and TFF 2005). The devolution of lands and resources is also driven by the desire to offload the direct costs of delivering programmes and services in the north, and so negotiations relating to human resources and administrative responsibilities are very much structured by these federal preferences. Finally, the federal government insists that although territorial governments should be able to benefit from on-shore natural resources development projects that fall within their borders post-devolution, the benefits that the territorial governments accrue from these resources cannot be disproportionate. Much like how provincial equalisation ensures that the entire country benefits from the uneven distribution of natural resources throughout the country, so too should the rest of Canada benefit from the natural resources located in the north.

In terms of territorial preferences, the three territorial governments have long been interested in furthering the political and constitutional development of their respective regions. A major component of that development is gaining administrative control over their land and resources. In 1905, the provinces of Alberta and Saskatchewan were created out of a portion of the NWT. However, it was only in 1930 that the federal government transferred lands and resources to these provinces. The territorial situation today is similar in that the territories have a variety of powers akin to what the provinces have. However, in the case of the NWT and Nunavut, they do not control their lands and resources. Territorial officials believe that the political and constitutional development of their territories requires that their governments gain control over these important jurisdictions, much like Alberta and Saskatchewan did in 1930.

In addition to gaining jurisdiction over lands and resources (Cunning 2010; GNWT 1989; Richardson 2011) to further the political and constitutional development of their regions (GNWT 1990), the territorial governments have a strong interest in negotiating a deal that maximises their economic independence from the federal government. This means gaining control over their lands and resources so that they can create a regulatory and administrative environment that is more efficient in addressing local needs and goals. It also means negotiating a deal that limits the financial liability of any economic developments approved by the federal government prior to devolution. Finally, and most importantly, territorial officials desire an agreement that includes a natural resource revenue provision that does not place unfair and restrictive restraints on the fiscal and policy capacity of the northern governments to address local concerns. This latter point is particularly important in that territorial governments want to keep every dollar generated from economic development and resource extraction projects within their borders. They do not want the federal government to significantly reduce federal transfer payments proportional to the natural resource revenues that the territorial governments generate post-devolution. Doing so would create significant disincentives for the territorial governments to pursue economic development and 
would prevent them from eliminating their dependence on the federal transfers (Bannon 2011; Handley 2011; McDonald 2010; Feehan 2009; GNWT 1993).

The final set of actors whose preferences need to be specified are the aboriginal groups in the territorial north. Although one might have assumed significant differences to exist among these groups, given their numbers and diversity, surprisingly their core preferences relating to devolution are remarkably similar. The main concern of aboriginal groups in all three territories is the impact of a devolution agreement on their current and future land claims/self-government negotiations and agreements. In Nunavut, for instance, the Nunavut Tunngavik Incorporated (NTI) supports natural resource devolution only if the final agreement 'does not abrogate or derogate from any rights of Inuit and the NLCA' [Nunavut Land Claims Agreement] (Mayer 2007: 22). In the Yukon Territory, all fourteen Yukon first nations expressed concerns that the federal and territorial governments of Canada had to complete comprehensive land claims agreements with the Yukon first nations before any devolution agreement could be achieved (Wright 1995: 9-10). According to Victor Mitander, Chief Negotiator, Council of Yukon First Nations, 'The Council of Yukon First Nations and Yukon first nations have historically been opposed to the devolution of lands and resources, and the basic reason is because there are a number of Yukon first nations that have yet to conclude their final and selfgovernment agreements. For those reasons we've asked that devolution should not proceed until we have concluded these agreements' (Canada 1997; see also Leas 2010; McDonald 1996).

A similar concern drives the preferences of the aboriginal groups in the NWT (Handley 2011). Aboriginal groups in the NWT have long been wary about the possible impact that devolution might have on their incomplete or completed land claims negotiations (GNWT 1998: 5-6; Wright 1995: 14-17). According to former Deh Cho Grand Chief Herb Norwegian, for instance, 'Canada has no right to transfer ownership or control over any land in the Deh Cho territory .... Not one grain of sand in the Deh Cho land belongs to Canada' (Raven 2005; see also Unrau 2007; Roland 2008; Thompson 2011). The Akaticho have expressed similar sentiments, saying that the timing for a devolution deal was wrong. 'It just doesn't make sense; it's not realistic. I think the time is wrong right now. The right timing could be when all the [land] claims are finalized' (CBC 2007; CBC 2010; Beauliu 2011). Those aboriginal groups that have completed land claims agreements have expressed concerns about the potential impact of devolution on their jurisdictions. They have also been critical of the lack of consultations undertaken by the Crown regarding how best to minimise the impact of the devolution agreement on indigenous autonomy. The Tlicho, for instance, have expressed reservations about the potential impact of the agreement on their completed land claims agreement (Makohoniuk 2010; Stokell 2011). Gwich'in leaders have stated that "this constitutional duty, judicially referred to as the "honour of the Crown," requires adequate and appropriate "consultation" and "accommodation" to address the concerns of the Aboriginal governments respecting the impact on existing Aboriginal and Treaty rights of the devolution process and terms of the signed Devolution AIP' (Gargan and Nerysoo 2011). The Sahtu share these concerns, stating that federal and territorial government officials 'are not listening at all' and that they 'were caught pretty much off guard' by the leaked AIP (May 2010; Yakeleya 2011).

A second aboriginal preference relating to the devolution of lands and resources is the desire to maximise the aboriginal share of the net fiscal benefit. Indeed, the nature of this round of devolution negotiations is such that the main negotiation issue is who should get what from the revenues generated by the development of natural resources in the territory. Aboriginal groups in all three territories are very much interested in ensuring that their governments receive a fair portion of the revenues generated. In Yukon, the first nations agreed to a formula that in essence gave them $50 \%$ of the net fiscal benefit that the territory received up to a cap of $\$ 2$ million, after which the benefit shrinks to $10 \%$ (Irlbalcher-Fox and Mills 2007: 6). In the NWT, aboriginal groups are pushing for something that is at least similar to the $50 \%$ formula that the Yukon first nations received. Indeed, some anonymous aboriginal interviewees claim that much of the rhetoric surrounding the effect of devolution on aboriginal land claims and the Crown's duty to consult prior to signing a final agreement are in fact negotiating strategies for forcing the GNWT to increase the aboriginal share of territorial resource revenues from $25 \%$ to $50 \%$. These same interviewees argue that most of the aboriginal opposition in the NWT would most likely disappear if the GNWT agreed to this change. NTI has been less vocal about this issue in Nunavut since devolution negotiations have not proceeded much beyond the completion of the protocol agreement.

Given these preferences, the following section illustrates how the different outcomes experienced by Yukon Territorial Government (YTG), GNWT, and GN are partially explained by the extent to which the territorial governments have been willing to negotiate an agreement that is compatible with the goals of the federal government. It also argues that varying perceptions of Aboriginal consent in the NWT and federal perceptions of Nunavut's lack of political maturity have prevented these territories from completing final agreements.

\section{Satisfying federal preferences}

Federal preferences in devolution negotiations revolve around the desire to maintain federal government revenue streams from natural resource developments in the territories, decrease its direct costs related to the administration of the territorial north, and ensure that territorial shares of natural resource revenues are consistent with the federal principles of equalisation. Both the Yukon 
devolution transfer agreement (YDTA) and the NWT devolution AIP contain provisions that are congruent with these goals. The net fiscal benefit provisions in the devolution agreements, for instance, are illustrative of how territorial officials were able to complete a devolution settlement by agreeing to provisions that were compatible with federal preferences to maximise federal revenues from territorial resources while respecting the principles of equalisation. In the YDTA, for instance, the territorial government annually is allowed to keep up to a maximum of \$3 million in revenues derived from natural resource developments (except for oil and gas), after which there is a dollar-for-dollar reduction in the annual Territorial Formula Financing (TFF) grant from the federal government (Government of Canada and Government of Yukon 2001: s. 7.27). For oil and gas revenues, the cap is the same except that the reduction in transfers is based on a sliding scale, starting at $60 \%$ and rising progressively to $80 \%$ (Feehan 2009: 355). Aboriginal groups that have signed the Umbrella Final Agreement (UFA) and have completed final agreements are entitled to $50 \%$ of the first \$2 million in royalties from mineral resources and 10\% thereafter' (Feehan 2009: 349). In the late 1990s and early 2000s, the level of natural resource development activity in the territory was negligible and so there was little risk that this formula would punish either government (Cameron 2010; Cunning 2010; McDonald 2010). However, in recent years, the level of mining activity has increased, leading territorial officials to lobby the federal government to renegotiate the cap (Yukon Government 2011).

The net fiscal benefit formula in the NWT devolution AIP is similar to Yukon, although different in scope, reflecting the fact that the NWT contains significantly more natural resources than does Yukon. As a result, GNWT officials have long argued that any devolution agreement had to ensure that the GNWT received every dollar produced from natural resource developments post-devolution (Braden 2011; Patterson 2011; Van Loon 2010). This difference in the scope and magnitude of natural resource reserves in the two territories and the insistence of GNWT officials that any net fiscal benefit formula had to contain provisions that did not result in clawbacks to federal transfers, made negotiating an agreement impossible to complete for the GNWT. The net fiscal benefit in the current NWT devolution AIP, however, represents a significant shift in the GNWT's negotiation position to one that is more compatible with federal preferences. The result is a completed AIP. According to chapter 12 of the AIP, for instance, $50 \%$ of resource revenues are excluded from 'the offset calculation against the GNWT's Territorial Formula Financing grant ... up to an overall fiscal capacity cap equal to 5 percent of the NWT's Gross Expenditure Base' (Government of Canada and Government of Northwest Territories 2010: s. 12.1b). In short, this means that should a final devolution agreement be reached, GNWT resource revenues will also be subject to a cap much like in Yukon, except that the cap is expressed as a percentage of the territory's gross expenditure base (GEB) rather than an exact dollar amount cap. In practice, for instance, this would have meant that the NWT cap last year would have been approximately $\$ 60$ million, based on a GEB of $\$ 1.2$ billion. Of that $\$ 60$ million, aboriginal signatories to the devolution agreement would have received $25 \%$ of territorial resource revenues, or \$15 million.

In sum, in both the NWT and Yukon, the federal and territorial governments were interested in maximising the potential revenues from natural resource developments. For the federal government, it was also interested in a net fiscal benefit that was consistent with the principles of equalisation. In Yukon, development activity and potential for activity at the time were significantly low so it was slightly easier for their officials to sign a devolution transfer agreement with a hard cap of \$3 million (Cameron 2010; Cunning 2010; McDonald 2010). In comparison, the NWT contains significantly more natural resource deposits and so negotiators were unable to generate a final agreement, let alone an AIP, until GNWT officials under the governments of Premiers Joe Handley and Floyd Roland were willing to accept a net fiscal benefit that distributed resource revenues in a way that was consistent with federal preferences. Government of Canada officials have long argued that the net fiscal benefit had to be consistent with the principles of equalisation in that no one province should benefit disproportionately from its natural resources. A number of anonymous federal and GNWT officials confirm that the net fiscal benefit formula had to meet this standard and that the GNWT AIP was completed mainly because territorial officials agreed to such a formula.

The devolution agreements were also consistent with territorial goals relating to wanting to take control over their lands and resources to further their political development. They were also consistent with federal interests in cutting costs (Robertson and others 2010). In the Yukon agreement, for instance, chapter 2 transferred control over territorial land and waters, while chapter 3 detailed the transfer of human resources to the territorial government. Chapters 4, 5, and 6 devolved authority over Northern Affairs Program properties, assets and contracts, forest resources, and environmental matters, including waste sites. Chapters 7 and 8 addressed continuing and one off financial transfers and the execution of the agreement.

All of these devolved jurisdictions and assets represented significant savings for the federal government. In terms of human resources, the federal government laid off approximately 250 federal employees, with the Yukon territorial government hiring back approximately $90 \%$ of those employees (O'Farrell 2010; McDonald 2010; Robertson and others 2010). In terms of fire suppression, several interviewees (Cunning 2010; Robertson and others 2010) reported that some officials have criticised the Yukon government for not getting enough funds in the agreement to cover the costs of fire suppression. The 
federal government agreed to pay for fire suppression on a sliding scale for the first five years after devolution at which point the territorial government would take on full responsibility. The fear among some residents of Yukon is that one extraordinary forest fire season could bankrupt the territorial government (Robertson and others 2010), thus illustrating the potential savings the federal government may be accruing through devolution. A number of YTG officials have also mentioned that the devolution of liability over waste sites was an immense cost-saving transfer for the federal government, despite the federal government agreeing to be liable for sites approved pre2003 and the YTG agreeing to be liable for post-2003 sites. The old Faro mine, for instance, has cost $\$ 500$ million dollars to remediate (Robertson and others 2010). Post-devolution, the federal government will continue to reap the financial benefits of future mining sites, after the YTG collects the first \$3 million in revenues, and pay none of the cleanup costs.

\section{Satisfying the aboriginal veto}

Although the GNWT did complete an AIP in 2010, only the YTG has signed a final devolution transfer agreement. The completion of both of these agreements was only possible once territorial officials became willing to sign an agreement that contained provisions that were compatible with federal preferences relating to revenues, costs and equalisation. What, then, explains the GNWT's lack of success in signing a final agreement? The main obstacle has been the lack of perceived aboriginal consent. In Yukon, the fourteen Yukon first nations were initially opposed to devolution because none of the aboriginal groups had completed their land claims agreements. Federal officials, and eventually, territorial officials, came to realise that 'a critical mass' of aboriginal support was necessary before any devolution agreement could be completed (Leas 2010; McDonald 2010; McKinnon 2010; Robertson and others 2010; Wright 1995: 9). In 1993, the Yukon first nations, represented by the Council for Yukon Indians, and the federal and Yukon governments, completed decades of treaty negotiations by signing the UFA. This provides the framework under which each Yukon first nation must negotiate its individual final agreement. In 1995, four Yukon first nations signed final agreements and by 2001, three more first nations had completed final agreements. This steady progress of completed treaties in combination with the signing of the UFA by all Yukon first nations in 1993 was seen by federal and territorial officials as clear indicators that aboriginal consent had been achieved, thus clearing the way for the signing of the Yukon DTA in 2001 (Leas 2010; Robertson and others 2010; Smyth 2010).

In contrast, the role and position of aboriginal groups in the NWT have been more complex (GNWT 1993: 2, 1996: 5, 2000: 1-2; Wright 1995: 14-16). In general, with some exceptions, the Yukon first nations have always been somewhat more cohesive than the aboriginal groups in the NWT. Whereas the Yukon first nations have tended to work together first through the Council of Yukon Indians and later the Council of Yukon First Nations, the aboriginal groups in the NWT have been less unified, with formal cooperation lasting briefly through the now-defunct aboriginal summit. Whereas all the aboriginal groups in Yukon signed the UFA at the same time and 11 groups completed final agreements in fairly rapid succession, only four groups in the NWT have completed comprehensive land claims agreements over a 20 year period (Inuvialuit in 1984; Gwich'in in 1992; Sahtu in 1993; Tlicho in 2003). As a result, federal and territorial officials in the GNWT have long sought for a more substantial indication of direct (that is signing the AIP) or indirect (that is a large number of completed land claims agreements) aboriginal consent regarding devolution. On 9 May 2007, GNWT Premier Joe Handley reached a separate agreement with aboriginal leaders from the Inuvialuit Regional Corporation, the Gwich'in Tribal Council, the Sahtu Secretariat Inc., and the NWT Metis Nation, regarding resource revenue sharing. In section $G$ of this agreement, the negotiating parties agreed that the aboriginal signatories 'shall be entitled to a share of up to $25 \%$ of the Net Fiscal Benefit to be used to promote political development and for the delivery of government programs and services in the NWT' (GNWT 2007: 3). Several federal and territorial anonymous interviewees suggested that government officials saw this agreement as successfully meeting the requirement for a critical mass of aboriginal support. The result was accelerated devolution negotiations and a draft AIP in 2010. Some might suggest that an additional explanatory factor may be related to the fact that some current Aboriginal leaders have served as territorial cabinet ministers and Premiers in the past and that these previous experiences may make negotiations easier to accomplish. However, the evidence is mixed. For instance, both Nellie Cournoyea of the IRC and Richard Nerysoo of the Gwich'in were once premiers of the NWT yet only Cournoyea is supportive of the current AIP.

Unfortunately for territorial officials, two of the original signatories to the 2007 GWNT-aboriginal resource revenue sharing agreement, the Gwich'in Tribal Council and the Sahtu Secretariat Incorporated, have since reneged on the agreement and decided not to support the 2010 AIP. Six anonymous aboriginal and/or territorial interviewees suggested that a change in political leadership within the two aboriginal groups was one of the main reasons why the groups no longer supported the devolution agreement. Another reason was that the aboriginal groups believed that the federal and territorial governments failed adequately to consult them during devolution negotiations. As a result, commentators suggest that the devolution deal is unlikely to be ratified. Anonymous interviewees also suggest that the fact that the main architect of the deal, former GNWT Premier Floyd Roland, decided not to run for re-election, indicates that the AIP is likely to be shelved. They suggest that aboriginal consent will only be achieved if adequate 
consultations, and more importantly, a dramatic rise in the aboriginal share of the net fiscal benefit, are achieved.

In sum, the evidence suggests that a completed final devolution agreement requires government officials to perceive that aboriginal consent has been achieved in some way. In the case of Yukon, federal and territorial officials were confident that consent had been achieved with the signing of the UFA and the rapid succession of final land claims agreements signed prior to 2001 . These findings are confirmed by interviews with federal, territorial, and aboriginal officials in Yukon. In the NWT, devolution negotiations did not progress very far for a long time for a variety of reasons, including the lack of perceived aboriginal consent. Once the GNWT was able to get four aboriginal groups to sign a side agreement relating to resource revenue sharing in 2007 , only then did federal and territorial officials believe that sufficient aboriginal consent had been achieved, leading to the successful negotiation of an AIP in 2010. However, progress on a final agreement has been stalled by two of the aboriginal groups withdrawing their support. Anonymous territorial and aboriginal interviewees suggest that it is highly likely that future devolution negotiations in the NWT will only proceed if the GNWT can somehow convince at least two additional aboriginal groups to endorse the AIP. These same interviewees suggest that this goal is possible if the GNWT agrees to raise the aboriginal share of the GNWT's net fiscal benefit to $50 \%$.

\section{Federal perceptions of territorial government maturity and capacity}

A final factor that determines variation in devolution negotiation outcomes is the federal government's perception of territorial maturity and capacity. A number of interviewees and archival data suggest that the differences in the rate at which devolution has been occurring in the territories is related to how the federal government perceives the level of maturity and capacity of the territorial governments. The data indicate that the YTG has long been viewed as an established and mature government with a capable bureaucracy, at least in comparison to the other territories, and that this fact has influenced the rate of devolution in all three territories (Bannon 2011; Braden 2011; Cameron 2010; Handley 2011; Rawson 2010; Smyth 2010; Van Loon 2010). For example, federal officials have long been impressed that the YTG adopted party politics, a form of politics that is more 'conventional' and familiar to federal officials than the consensus system in the NWT. Indeed, one anonymous government official mentioned that a federal minister of Indian Affairs during the mid 2000s told federal and territorial officials in private meetings that he was not impressed with the status of governance in the NWT, specifically referencing the consensus government system used by the GNWT. This federal position has historical roots. In a speech given in Whitehorse in 1969, for instance, then Minister of Indian Affairs, Jean Chretien stated that based on 'your much greater percentage of residents already familiar with the institutions and traditions of responsible, responsive government...' that the Yukon was 'in a stronger position than the people in the Northwest Territories to accept a considerable measure of local responsibility for government' (Chretien 1969: 3).

Complicating matters further were discussions at the time surrounding the creation of Nunavut out of the eastern portions of the NWT. In the mid 1990s, the federal government commissioned Robert Wright to assess the feasibility of completing devolution in the NWT and Yukon. In 1995, Wright delivered his report to then Indian Affairs Minister Ron Irwin. Based on his research, he recommended that the federal government move quickly to devolve all remaining province-like powers to the YTG within a 18 month to two year time frame. He believed that the YTG had the capacity to take on these responsibilities. In contrast, he suggested that the federal government devolve province-like powers to the GNWT at a much slower rate to allow for the GNWT to complete the process of creating Nunavut out of its territories. Once that division was completed, only then could devolution proceed for the NWT (Wright 1995). In sum, the fact that Yukon achieved devolution before the NWT is partly the result of the federal government's different perceptions of the political development and maturity of the two territories.

The importance of federal government perceptions is more starkly illustrated in the case of Nunavut. Indeed, devolution negotiations have not moved beyond the protocol agreement mainly because of federal perceptions of Nunavut's capacity. The GN's well documented growing pains have made federal officials reluctant to pursue devolution negotiations until the GN can properly address its capacity issues, which include satisfying the s. 23 of the Nunavut Land Claims Agreement requirement to hire Inuit officials, and simply filling vacant positions in the regional government offices (Rawson 2011; Cameron and Campbell 2009: 216). This requirement to demonstrate capacity as a precondition for devolution was confirmed in a recent government report written by lawyer Paul Mayer for the federal government in 2007 (Mayer 2007). In that report, he found that GN faced enormous challenges in undertaking its current responsibilities, which is partly due to lacking sufficient human resources within the territorial bureaucracy. In 2010, for instance, GN had over 900 vacant positions in its bureaucracy (GN 2010). This is out of a total population of 33,330 (as of 1 October 2011) As a result, Mayer suggested that devolution in Nunavut should not occur until this capacity issue was satisfactory addressed: 'if the human resource capacity issue cannot be satisfactorily dealt with, then the right conditions will not be in place to transfer federal responsibilities (Mayer 2007: 46-47). The fact that the federal government agrees with this position is reiterated in Nunavut Hansard. According to Nunavut Legislative Assembly member Moses Aupaluktuq, for instance, 'this week's Budget Address that was delivered by our Minister of Finance stated that and I quote, 
"from our conversations with the federal government, we understand that they have not seen clearly that we are prepared to handle additional responsibilities"" that would flow from a devolution agreement (Government of Nunavut 2010: 12). Until federal officials perceive GN as having sufficient capacity and maturity to undertake its current responsibilities and jurisdictions, the evidence suggests that the federal government will not engage in further devolution negotiations with GN.

\section{Conclusion}

This paper has argued that variation in devolution negotiation outcomes relating to lands and resources can be explained by examining three sets of factors. First, in light of the federal government's dominant position in negotiations, territorial negotiators must negotiate an agreement that is compatible with federal preferences relating to resource revenues, equalisation, and the reduction of costs. Both the YTG and the Handley/Roland GNWT governments were willing to satisfy federal preferences in this manner. However, only the YTG has been able to complete a final agreement. The reason that YTG has been successful whereas the GNWT has not is because devolution negotiation outcomes also depend on the extent to which government officials perceive that sufficient aboriginal consent has been obtained. In Yukon, the fact that all of the Yukon first nations signed the UFA in 1993 and that a majority of aboriginal groups completed lands claims agreements at a fairly brisk rate were sufficient for federal and territorial negotiators to sign a DTA. In the NWT, in contrast, an AIP was negotiated only after the consent of four aboriginal groups was obtained in a 2007 resource revenue sharing agreement. However, the fact that two of the four groups have withdrawn their support means that the GNWT AIP is likely to be shelved or scrapped.

The final factor that determines variation in devolution negotiation outcomes is federal perceptions of territorial capacity and maturity. The evidence suggests that the different timing of devolution in the NWT and Yukon was partly the result of the YTG being seen as more mature and politically developed than the GNWT. A more stark example is the status of Nunavut devolution negotiations, which have not proceeded beyond the negotiation of a protocol agreement. The evidence suggests that the lack of progress on the Nunavut file is mainly the result of federal reluctance to negotiate with a government that it believes does not have the capacity to undertake its current responsibilities and obligations, let alone those that would flow from a final devolution agreement.

\section{Acknowledgements}

This research was funded by a SSHRC Strategic Research Grant, Northern Communities: Towards Social and Economic Prosperity, grant \#866-2008-0003. The author would like to thank Steven Kennedy, Eric Merkley, and Greg Whitfield for their research assistance as well as the interviewees who generously shared their time and expertise. The author would also like to thank the two anonymous reviewers of this journal for their helpful advice on an earlier version of this manuscript. All interviews were with the author except where indicated. The list of interviewees include: Armstrong, M.J. Director, Indian Affairs and Northern Canada. Ottawa, ON, 22 March 2010; Bannon, P. 2011. former Federal and GNWT official. Yellowknife, NT, 11 July; Braden, G. Former Premier of the GNWT and current Policy Analyst for Senator Dennis Patterson of Nunavut. Ottawa, ON, 14 June 2011; Dewar, B. 2010. Former INAC official. Ottawa, ON, 24 March 2010; Handley, J. Former Premier of the GNWT. Whitehorse, NT, 11 July 2011; Leas, D. Legal Counsel, Council of Yukon first nations. Interview with Steven Kennedy. Whitehorse, YT, 22 November 2010; McDonald, P. Former Premier of the Yukon Government. Interview with Steven Kennedy. Whitehorse, YT, 15 November 2010; McKinnon, K. YESAB Official, Yukon Territorial Government. Interview with Steven Kennedy. Whitehorse, YT, 23 November 2010; O'Farrell, J. Deputy Minister, Community Services. Interview with Steven Kennedy. Whitehorse, YT, 15 November 2010; Rawson, B.. Chief Federal Representative for Nunavut. Ottawa, ON, 22 March 2010; Richardson, H. Former Executive Director of the Office of Devolution, Government of the Northwest Territories. Yellowknife, NT, 12 July 2011; Smyth, S. Assistant Deputy Minister, Executive Council Office. Interview with Steven Kennedy. Whitehorse, YT, 17 November 2010; Van Loon, R. Former Associate Deputy Minister of Indian Affairs. Ottawa, ON, 22 March 2010. The other interviewees whose data were used for this paper requested anonymity.

\section{References}

Abele, F., T. Courchene, F.L. Seidle, and F. St-Hilaire. (editors). 2009. Northern exposure: peoples, powers and prospects in Canada's north. Montreal: IRPP.

Abele, F., and M.J. Prince. 2008. A little imagination required: how Canada funds territorial and northern aboriginal governments. In: Maslove, A. (editor). How Ottawa spends 2008-09. Montreal-Kingston: McGill-Queen's University Press.

Alcantara, C. 2007. Explaining aboriginal treaty negotiation outcomes in Canada: the cases of the Inuit and the Innu in Labrador. Canadian Journal of Political Science 40(1): 185207.

Alcantara, C. 2008. To treaty or not to treaty? Aboriginal peoples and comprehensive land claims negotiations in Canada. Publius: Journal of Federalism 38(2): 343-369.

Beauliu, T. 2011. Member's statements. Northwest Territories Legislative Assembly. Hansard. 16th Assembly, 5th Session, 4 February 2011.

Bone, R. M. 2002. The three territories: an introduction. In: The Canadian north: embracing change. Ottawa: Centre for Research and Information on Canada.

Cameron, K., and A. Campbell. 2009. The devolution of natural resources and Nunavut's constitutional status. Journal of Canadian Studies 43(2): 198-219. 
Cameron, K., and G. White. 1995. Northern governments in transition. Montreal: Institute for Research on Public Policy.

Cameron, K., and G. Gomme. 1991. The Yukon's constitutional foundations. Vol. II. A compendium of documents relating to the constitutional development of the Yukon territory. Whitehorse: Northern Directories.

Canada. 1898. An act to provide for the government of the Yukon District. Ottawa: Department of Public Works and Government Services. URL: http://www.solon.org/Constitutions/ Canada/English/yta_1898.html (Accessed 2 October 2009).

Canada. 1997. Evidence presented to the Standing Committee on Aboriginal Affairs and Northern Development. 4 November1997. Ottawa: Department of Public Works and Government Services.

CBC (Canadian Broadcasting Corporation). 2007. Akaitcho chiefs demand N.W.T. premier's resignation. Canadian Broadcasting Corporation News North 16 May 2007.

CBC (Canadian Broadcasting Corporation). 2011. N.W.T. signs on for province-like powers. Canadian Broadcasting Corporation News North 26 January 2011.

Clancy, P. 1990. Politics by remote control: historical perspectives on devolution in Canada's north. In: Dacks, G. (editor). Devolution and constitutional development in the Canadian north. Ottawa: Carleton University Press: 13-42.

Chretien, J. 1969. Speech by the Honourable Jean Chretien, P.C., M.P., Minister of Indian Affairs and Northern Development before the Yukon Territorial Council. 12 November 1969. Ottawa: Department of Indian Affairs (MG 32 B22 29-7).

Coates, K.S., P.W. Lackenbauer, W. R. Morrison, and G. Poelzer. 2009. Arctic front: defending Canada in the far north. Toronto: Thomas Allen Publishers.

Coates, K.S., and W.R. Morrison. 2005. Land of the midnight sun: a history of the Yukon. Montreal: McGill-Queen's University Press.

Dacks, G. 1990. Devolution and constitutional development in the Canadian north. Ottawa: Carleton University Press.

Dacks, G., and K.S. Coates. 1988. Northern communities: the prospects for empowerment. Edmonton: Boreal Institute for Northern Studies.

Dickerson, M.O. 1992. Whose north? Political change, political development and self-government in the Northwest Territories. Vancouver: UBC Press/Arctic Institute of North America.

Expert Panel on Equalization and TFF. 2005. Discussion paper: Key Issues for the review of equalization and territorial formula financing. 31 March 2005. Ottawa: Department of Public Works and Government Services.

Feehan, J. 2009. Natural resource devolution in the territories: current status and unresolved issues. In: Abele, F., T. Courchene, F.L. Seidle, and F. St-Hilaire. Northern exposure: peoples, powers and prospects in Canada's north. Montreal: IRPP.

Gargan, S., and R. Nerysoo. 2011. Letter to Prime Minister Harper: NWT lands and resource devolution agreement-inprinciple. 26 January 2011. Inuvik.

Government of Canada, Government of Nunavut, and Nunavut Tunngavik Incorporated. 2008. Lands and resources devolution negotiation protocol. Ottawa: Department of Public Works and Government Services.

Government of Canada and Government of the Northwest Territories. 2010. Northwest Territories lands and resources devolution agreement-in-principle. Ottawa: Department of Public Works and Government Services.

Government of Canada, Government of the Northwest Territories, and the Aboriginal Summit. 2004. Northwest Territories lands and resources devolution framework agreement.
Ottawa: Department of Public Works and Government Services.

Government of Canada and Government of the Yukon. 2001. Yukon Northern Affairs Program devolution transfer agreement. Ottawa: Department of Public Works and Government Services.

GNWT (Government of Northwest Territories). 1989. Principles underlying the GNWT position on the relationship between claims implementation and devolution. 30 November 1989. Yellowknife: NWT Archives G-2006-003, 13-5.

GNWT (Government of Northwest Territories). 1990. Background: devolution/implementation working group. Yellowknife: NWT Archives G-2007-006, 4-10.

GNWT (Government of Northwest Territories). 1993. Notes of meeting with Hiram Beaubier and Bernie Funston. Ottawa. 7 April 1993. Yellowknife: NWT Archives G-2007-006, 2-2.

GNWT (Government of Northwest Territories). 1995. Devolution speaking points for consideration. Yellowknife: NWT Archives G-2007-006, 2-12.

GNWT (Government of Northwest Territories). 1996. Decision paper: devolution of natural resources. 16 May 1996. Yellowknife: NWT Archives G-2007-006, 1-3.

GNWT (Government of Northwest Territories). 1998. NWT Resource revenue sharing: a discussion paper. 1 July 1998. Yellowknife: NWT Archives G-2004-024, 2-1.

GNWT (Government of Northwest Territories). 2000. Devolution: aboriginal issues in devolution negotiations. Yellowknife: NWT Archives G-2004-024, 2-2.

GNWT (Government of Northwest Territories). 2007. Resource revenue sharing agreement-in-principle. 9 May 2007. Yellowknife.

Government of Nunavut. 2010. Nunavut Hansard. 11 March 2010.

Grady, P. 2001. Approaches for resource revenue sharing among Northwest Territories governments. Yellowknife: NWT Archives G-2004-024, 2-1.

Health Canada. 2005. Ten years of health transfer first nations and Inuit control. Ottawa: Department of Public Works and Government Services. URL: http://www.hc-sc.gc.ca/fniahspnia/pubs/finance/_agree-accord/10_years_ans_trans/index -eng.php (accessed 3 November 2009).

Henderson, A. 2007. Nunavut: rethinking political culture. Vancouver: UBC Press.

Hurley, M.C. 2002. Bill C-39, The Yukon Act. Ottawa: Government of Canada: Law and Government Division. URL: http:// www2.parl.gc.ca/Sites/LOP/LegislativeSummaries/ Bills_Is. asp?lang $=\mathrm{E} \& \mid \mathrm{s}=\mathrm{C} 39$ \& source $=$ library_\%20prb\&Parl $=37 \&$ Ses $=1$ (accessed 2 November 2009).

Intergovernmental Affairs and Aboriginal Affairs. 1995. Briefing note: progress on devolution of land and water. 7 March 1995. Yellowknife: NWT Archives G-2007-006, 2-12.

Intergovernmental Affairs and Aboriginal Affairs. 1994. Briefing note: federal devolution of natural resource management. 17 August 1994. Yellowknife: NWT Archives G-2007-006, 2-12. Intergovernmental Core Group. 1993. Northwest Territories development: division, the western constitution, devolution. 14 October 1993. Yellowknife: NWT Archives: G-2007-006, 3-4. Irlbacher-Fox, S., and S.J. Mills. 2007. Devolution and resource revenue sharing in the Canadian north: achieving fairness across generations. Toronto (Conference paper for the Walter and Duncan Gordon Foundation).

King, G., R.O. Keohane, and S. Verba. 1994. Designing social inquiry: scientific inference in qualitative research. Princeton: Princeton University Press.

Legislative Assembly of the Northwest Territories. 2010. History of the Legislative Assembly. Yellowknife: The Legislative 
Assembly of the NWT. URL: http://www.assembly.gov.nt. ca/_livelpages/wpPages/factshistoryofthelegislativeassembly. aspx (accessed 15 July 2010).

Makohoniuk, R. 2010. Tlicho government does not support the draft devolution AIP. Tlicho Government Press Release 29 October 2010.

May, K. 2010. Aboriginal leaders sound off on devolution. Northern News Services 1 November 2010.

Mayer, P. 2007. The Mayer Report on Nunavut devolution. Ottawa: Department of Indian and Northern Affairs.

McArthur, D. 2007. The changing architecture of government in northern Canada west of Nunavut. Ottawa (Paper delivered at The Art of the State IV: Northern exposure), Institute for Research on Public Policy.

McDonald, P. 1996. Oral questions. Whitehorse: Yukon Legislative Assembly. Hansard. 28th Legislature, 2nd Session. 25 March 1996.

Memorandum of Intent on Devolution and Resource Revenue Sharing. 22 May 2001. (Copy with author).

Michael, J.M. 1987. From Sissons to Meyer: the administrative development of the Yukon Government 1948-1979. Whitehorse: Yukon Archives.

Morrison, D.R. 1968. The politics of the Yukon Territory, 18981909. Toronto: University of Toronto Press.

Natcher, D.C., and S. Davis. 2007. Rethinking devolution: challenges for aboriginal resource management in the Yukon Territory. Society and Natural Resources 20(3): 271279.

O'Brien, A. 2006. Strengthening Canada's territories and putting equalization back on track. Kingston: Institute of Intergovernmental Relations (The Report of the Expert Panel on Equalization and Territorial Formula Financing).

Okalik, P. 2006. Devolution and nation building in Canada's north. Iqaluit: Government of Nunavut (Speech to the Public Policy Forum Seminar on Economic Transformation North of 60.13 December 2006).

Raven, A. 2005. Feds have no right: DFN. Northern News Services. 18 March 2005.
Rayner, J. 2001. Fiscal Relations Between the Federal and Territorial Governments in Canada. Consortium for Economic Policy Research and Advice.

Roland, F. 2008. Oral questions. Northwest Territories Legislative Assembly. Hansard. 16th Assembly, 5th Session, 18 October 2008.

Simeon, R. 2006. Federal-provincial diplomacy: the making of recent policy in Canada. Toronto: University of Toronto Press.

Smyth, S. 1991. The Yukon's constitutional foundations, Vol. I. The Yukon chronology. Whitehorse: Northern Directories.

Stokell, S. 2011. New Tlicho grand chief to focus on 'unity'. Northern News Service 28 March 2011.

Thompson, R. 2008. Dehcho first nations examine its options. Northern News Service 3 February 2008.

Tsebelis, G. 2002. Veto players: how political institutions work. Princeton: Princeton University Press.

Unrau, J. 2007. Handley brushes off Akaitcho demand that he leave town. Northern News Service. 21 May 2007.

White, G. 2009. Nunavut and the Inuvialuit settlement region: differing models of northern governance. In: Abele, F., J.T. Courchene, F.L. Seidle, and F. St-Hilaire (editors). Northern exposure: peoples, powers and prospects in Canada's north. Ottawa: The Institute for Research on Public Policy.

White, G. 2002. Politics and government in the territorial north: familiar and exotic. Ottawa: Centre for Research and Information on Canada (The CRIC Papers - The Canadian north: embracing change. June 2002).

Wright, R. 1995. Report to the Honourable Ronald Irwin re The devolution by DIAND of provincial-like powers to the Yukon and Northwest Territories. Ottawa: INAC.

Yakeleya, N. 2011. Members' statements. Yellowknife: Northwest Territories Legislative Assembly. Hansard. 16th Assembly, 5th Session, 16 February 2011.

Yukon Government. 2011. Yukon welcomes PM's commitment to improve resource revenue sharing agreement. Press Release \#11-132. Whitehorse: Yukon Government.

Zaslow, M. 1988. The northward expansion of Canada, 19141967. Toronto: McClelland and Stewart. 